DZIEJE NAJNOWSZE, ROCZNIK XLVII - 2015, 4

PL ISSN 0419-8824

\author{
Marek Kazimierz Kamiński \\ Warszawa
}

\title{
Polska pod naciskiem mocarstw zachodnich (styczeń-lipiec 1938 r.)
}

Rok 1938 stanowił zapowiedź brzemiennych w skutki wydarzeń prowadzących do wybuchu drugiej wojny światowej. Szefem polskiej dyplomacji był minister spraw zagranicznych Józef Beck. Widział on rolę Polski jako mocarstwa regionalnego, prowadzącego niezależną politykę i mającego decydujący udział w kształtowaniu losu swego regionu. Odrzucał natomiast definicję Polski jako tzw. wielkiego mocarstwa jak Francja czy Wielka Brytania. Beck odnotował, jak wyglądają stosunki z obcymi dyplomatami: „z Francuzami chłodno, z Anglikiem o włos lepiej niż z Francuzem". Churchill, aktywny na niwie brytyjskiej polityki zagranicznej, w rozmowie z polskim ambasadorem w Wielkiej Brytanii Edwardem Raczyńskim, oświadczył 27 I 1938 r., że Beck nie jest ani ,antyfrancuski”, ani ,proniemiecki”, ale ,propolski”. Dla Brytyjczyka nie ulegało zatem wątpliwości, że polski minister spraw zagranicznych reprezentuje polską rację stanu, nie zaś francuską czy niemiecką ${ }^{1}$.

23 II 1938 r. podczas rozmowy Becka z marszałkiem Hermannem Göringiem, bardzo bliskim współpracownikiem niemieckiego dyktatora Hitlera, w trakcie jego wizyty w Polsce polski minister zaproponował przedłużenie ważności polsko-niemieckiej deklaracji o niestosowaniu przemocy z 26 I 1934 r. W trakcie wymiany zdań Beck zaznaczył, że ,jest to tylko luźna koncepcja”. Minister Beck rzucił „luźno myśl, by ewentualnie przy rewizycie [nowego niemieckiego ministra spraw zagranicznych Joachima] von Ribbentropa w Warszawie przedłużyć akt z 1934 r." Göring zaś wyraził opinię, iż ,układ powinien być przedłużony na 20-25 lat, tak aby było jasne, że stosunki polsko-niemieckie są oparte na trwałej podstawie”. Podczas spotkania 23 II 1938 r. Beck ,pporuszył wobec Göringa sprawę Czechosłowacji oraz wizyty w Warszawie min. von Ribbentropa; zaznaczył przy tym, że można by wykorzystać tę wizytę dla przedłużenia na dalsze 15 lat układu ze stycznia 1934”. Według zapisu polskiego wiceministra spraw zagranicznych Jana Szembeka „Göring podchwycił ten punkt dość skwapliwie i oświadczył, że koncepcję wysuniętą przez [polskiego] ministra będzie w Berlinie popierał". Nie spotkała się ona jednak z pozytywnym przyjęciem ze strony Ribbentropa. Podczas rozmowy 18 III 1938 r. polskiego ambasadora w Berlinie Józefa Lipskiego z niemieckim ministrem spraw zagranicznych Ribbentrop oświadczył, iż „oczywiście nie może

\footnotetext{
${ }^{1}$ Polskie Dokumenty Dyplomatyczne, 1938 (dalej: PDD), red. M. Kornat, Warszawa 2007, s. 63, 64, $149,154$.
} 
się miarodajnie wypowiedzieć i musi się najpierw porozumieć z Göringiem [w sprawie przedłużenia deklaracji o niestosowaniu przemocy]". Niemiecki dyplomata udawał, że nic nie wiedział o rozmowie Becka z Göringiem. Pozwolił sobie jednak na konstatację, iż „na pierwszy rzut oka zastanawia się nad tym, czy tak dobrze funkcjonujący układ, zawarty między dwoma wodzami narodów, nie osłabi się w opinii [publicznej] przez przedterminowe przedłużanie go”. Lipski zaprzeczył temu, wskazując, że „to właśnie przez przedłużenie usunie się ten moment prowizoryczności"2.

Stosunek Polski do Czechosłowacji był nacechowany głęboką niechęcią. 13 I 1938 r. Beck w rozmowie z poprzednikiem Ribbentropa na stanowisku szefa niemieckiej dyplomacji Konstantinem von Neurathem ,podkreślił, że mimo liberalnej konstytucji Czechy prowadzą w stosunku do mniejszości najostrzejsze formy państwa policyjnego". Neurath ział wręcz nienawiścią do państwowości czechosłowackiej. Utrzymywał, że „tak jak dziś rzeczy się przedstawiają prędzej lub później ta ślepa kiszka [tzn. Czechosłowacja] musi być wycięta”. Tymczasem Ribbentrop zaczynał odgrywać coraz większą rolę w gronie skupionych wokół Hitlera najwyższych funkcjonariuszy nazistowskich Niemiec. Nie będąc jeszcze ministrem, lecz ambasadorem w Londynie, wysłał do Hitlera poufny memoriał datowany 2 I 1938 r., poświęcony tworzeniu antybrytyjskiej koalicji. Niemcy, dążąc do wyznaczonego celu, powinny zdaniem Ribbentropa nie tylko zacieśniać przyjaźń z Włochami i Japonią, ale również starać się pozyskać „wszystkie narody, których interesy zbiegają się pośrednio lub bezpośrednio z niemieckimi”. Można sądzić, biorąc też pod uwagę późniejsze postępowanie przywódców Trzeciej Rzeszy, że w odróżnieniu od ich stosunku do Czechosłowacji do Polski odnosili się jak do potencjalnego uczestnika koalicji antybrytyjskiej. Problem jednak polegał na tym, iż miejsce, które gotowi byli przyznać Polsce w tym układzie, oznaczało zrzeczenie się przez nią niepodległości. Na to zaś władze w Warszawie w żadnym wypadku nie chciały i nie mogły się zgodzić. Z góry odrzucały ewentualność kierowania państwem wasalnym, którego wzorzec został później wypracowany przez polityków słowackich. 13 I 1938 r. „Minister von Neurath wyraził się korzystnie o [francuskim ministrze spraw zagranicznych] Yvonie Delbosie”, natomiast „Minister Beck podkreślił toż samo, zaznaczając, że p. Delbos [podczas pobytu] w Warszawie [w dniach 3-7 XII 1937 r.] wykazał pełne zrozumienie jako realnie myślący polityk dla faktu, iż Polska musi prowadzić swoją niezależną politykę zagraniczną"3.

W trakcie rozmowy 26 I 1938 r. Becka z brytyjskim ministrem spraw zagranicznych Anthonym Edenem polski minister wyraził przekonanie, że ,p. Delbos poinformował zapewne rząd brytyjski o rezultatach swojej wizyty w Warszawie, w czasie której zdecydowanie potwierdziliśmy [strona polska] nasze zobowiązanie sojusznicze wobec Francji”. Jak zauważył wiceminister Szembek 28 I 1938 r., ,charakterystyczne jest, że w czasie wizyty swej w Pradze [8-11 XII 1937 r.] był dla Czechów bardzo zimny i nie tylko był daleki od obiecywania im jakiejkolwiek pomocy, ale nawet wskazywał na konieczność pójścia na wyraźne koncesje wobec Rzeszy”. „Jakże dalecy jesteśmy — z sarkazmem stwierdzał Szembek — od czasu, kiedy Francja «rządziła» Europą w otoczeniu satelitów. Zdaje się, że to ona z kolei stała się dzisiaj satelitą Anglii”. 27 I 1938 r. polski ambasador w Londynie Edward Raczyński skorzystał z okazji, że Churchilla nurtował problem ,czy Polska stanie w chwili kryzysu przy aliantach", tzn. po stronie Zachodu, i zadał pytanie, co uczyniłaby Wielka Brytania w razie konfliktu ,przede wszystkim o Czechy”. Churchill odpowiedział, ,że Francja niechybnie stanęłaby w obronie Czech, mobilizując siły zbrojne niezwłocznie w razie potrzeby”. „Anglia

\footnotetext{
${ }^{2}$ Ibidem, s. 109, 112-114; Diariusz i teki Jana Szembeka, 1972 (DTJS), t. IV, s. 50, 51.

${ }^{3}$ PDD, 1938, s. 12, 15, 18, 19; J. Lipski, Stosunki polsko-niemieckie przed wybuchem wojny w świetle aktów norymberskich, „Sprawy Międzynarodowe”, Londyn 1947, s. 11, 22, 23.
} 
jest - kontynuował brytyjski mąż stanu — w położeniu odmiennym, nie będąc związaną żadnymi zobowiązaniami w odniesieniu do tej części Europy. Toteż Anglia — zdaniem Churchilla - nie wystąpiłaby czynnie, przynajmniej na pierwszym etapie. Natomiast z pewnością określiłaby swoje (wrogie) stanowisko wobec niemieckiej agresji w sposób niedwuznaczny”. „Być może nawet - snuł swoje przypuszczenia brytyjski polityk — że tą drogą [Anglia] zostałaby ostatecznie wciągnięta do czynnego wystąpienia" ${ }^{\text {. }}$

Strona francuska zachowywała się wobec strony polskiej w sposób protekcjonalny, co musiało drażnić polskich polityków. Wiceminister Szembek w liście do posła w Belgradzie Romana Dębickiego z 15 II 1938 r. donosił poufnie że Léon Noël, ambasador francuski w Warszawie, przyszedł prosić Becka o zaniechanie planowanej podróży do Rzymu. „Krok tym dziwniejszy, że Minister jeszcze w Genewie Delbosa o swej jeździe włoskiej uprzedził” - skomentował Szembek postępowanie francuskiego polityka. Beck „oczywiście interwencję tę odrzucił. Powiedział tylko, że nie jedzie zawierać aliansu z Mussolinim, oraz obiecał jedynie, że zażąda od Włochów, by jego wizyta nie była komentowana w sensie antyfrancuskim". Prowadzenie przez polski rząd samodzielnej polityki było traktowane przez Francję jako zamach na jej rzekome prawa odgrywania wiodącej roli wobec państw, które uważała za mniej liczące się w porządku europejskim. 19 II 1938 r. doszło do rozmowy polskiego radcy ambasady w Paryżu Feliksa Frankowskiego z francuskim ministrem spraw zagranicznych Delbosem. Polski dyplomata odczytał instrukcję Becka, którą Delbos dosłownie zanotował. Wyraził przy tym opinię, że wizyta „Pana Ministra [Becka] w kraju, z którym stosunki Francji są dziś tak naprężone, jest dla niego nieprzyjemna, czemu dał już wyraz w rozmowie z Panem Ministrem [Delbosem] w Genewie”. Frankowski stwierdził wówczas, iż „rząd francuski powinien być jak najbardziej zadowolony, że w trudnej sytuacji, jaka się wytworzyła między Francją a Italią, inicjatywa Pana Ministra daje mu okazję do spróbowania odprężenia stosunków z Włochami i do zejścia w korzystnym dla pokoju kierunku z martwego punktu, na jakim się te stosunki znajdują". W dalszej części rozmowy dotknięte zostały bardziej ogólne kwestie. To, co dotychczas zostało omówione, wskazywało na upór strony francuskiej w domaganiu się respektowania szczególnej pozycji Francji na arenie międzynarodowej.

Frankowski, przekazując Delbosowi myśli Becka, twierdził, że „w chwili obecnej, gdy mamy do czynienia w dziedzinie międzynarodowej z ustabilizowaną nierównowagą, która to konstrukcja, jeżeli pozostawić samej sobie, może wytworzyć jak największe niebezpieczeństwa, nie wydaje się być celowem, pasywnie czekać na zrealizowanie tych niebezpieczeństw”. Według Frankowskiego ,podróż Pana Ministra do Rzymu może mieć poważne znaczenie, a inicjatywa Pana Ministra, którą mu [Delbosowi] zakomunikowałem pod chwilą, powinna być oceniana przez rząd francuski jako fakt bardzo pożądany i korzystny”. Strona francuska nie spieszyła się jednak z realizacją polskiego pomysłu przyczynienia się do zbliżenia Francji z Włochami. Natomiast trwająca w dniach od 6 do 15 III 1938 r. wizyta Becka w Rzymie nie przyniosła żadnych wymiernych rezultatów sprzyjających utrzymaniu pokoju światowego. Delbos w rozmowie z Frankowskim okazał się przeciwnikiem układów bilateralnych między państwami, opowiadając się za układami multilateralnymi. Frankowski zwracał uwagę, iż „,wobec niemożliwości osiągnięcia wspólnych porozumień, racja stanu zmusza do porozumień bilateralnych". Delbos utrzymywał, że wspólne niebezpieczeństwo grozi Francji i Polsce ze strony Niemiec, oraz twierdził, że ,jest bardzo zasmucony trwaniem negatywnego stosunku Polski do Czechosłowacji”. Frankowski wytknął Delbosowi, że „,do uło-

\footnotetext{
${ }^{4}$ PDD, 1938, s. 53, 63, 64.

${ }^{5}$ Ibidem, s. 74, 76, 91.
} 
żenia się obecnej sytuacji w takich formach, w jakich się przedstawia teraz, przyczyniła się w znacznej mierze polityka francuska, która w regionie, w którym Francja nie posiada sama bezpośrednich interesów, nie dość rozumiała i liczyła się z tymi bezpośrednimi interesami, które tam posiada Polska”. Zdaniem Frankowskiego „o ile dla Francji Rosja Sowiecka może być brana pod uwagę jako ewentualny sojusznik (tu p. Delbos żywo i dość powierzchownie zareagował, precyzując, że Francję łączy z Rosją traktat czysto defensywny, wzajemnej pomocy) to dla Polski kwestia Rosji przedstawia się z jeszcze z innego punktu widzenia, a mianowicie jako potencjalnie możliwe niebezpieczeństwo, nie mniejsze od niemieckiego". Delbos w trakcie rozmowy z Frankowskim ,pprzytaczał szereg argumentów mało interesujących dla dowiedzenia, że niebezpieczeństwo rosyjskie dla Polski jest znacznie mniejsze niż niemieckie, a że dla Francji gwarancja pomocy rosyjskiej jest bardzo ważną"6.

W połowie marca 1938 r. miało miejsce bardzo ważne wydarzenie z punktu widzenia porządku europejskiego. Niemcy hitlerowskie dokonały anszlusu Austrii, czyli wcielenia tego państwa do terytorium Trzeciej Rzeszy. Formalnie nastąpiło to 13 III 1938 r., faktycznie zaś proces zajmowania Austrii rozpoczął się nieco wcześniej. Wiceminister spraw zagranicznych Jan Szembek w liście z 5 III 1938 r. do posła polskiego w Belgradzie Romana Dębickiego twierdził, że „,wszystko wskazuje na to, że z chwilą załatwienia się z Austrią, Niemcy wezmą się do Czechosłowacji”. „Na tle tego wszystkiego osłabienie Francji jest może nawet niepokojące” — pisał Szembek. Francji — jego zdaniem ,nie pozostaje chyba nic innego, tylko wspólna linia z Anglią, tylko wydaje mi się, ze kiedy do niedawna szły ze sobą pod rękę, to obecnie zdaje się, że Anglia będzie prowadziła swą towarzyszkę za rękę". Zdaniem Szembeka „,spacer zaś niezbyt wygodny, skoro się zważy, że Anglia rozmawia z Włochami, które uważane są dzisiaj we Francji [...] za największego jej wroga, oraz odmawia wspólnej démarche w sprawie austriackiej, wyraźnie dążąc do menażowania [oszczędzania] Niemiec". Wiceminister spraw zagranicznych zauważył, że „w tej chwili sprawa czeska coraz silniej wzrasta i nie wiem, czy nie zbliża się chwila, kiedy trzeba będzie zgłosić się po część sukcesji" ${ }^{7}$.

Ciekawy był stosunek włoskiego dyktatora Benita Mussoliniego do państwa czechosłowackiego. Podczas wizyty Becka w Rzymie w dniach 7-9 III 1938 r. polski minister usłyszał od duce oraz włoskiego ministra spraw zagranicznych Galeazza Ciano, że „egzystencja lub nieegzystencja tego państwa [tzn. Czechosłowacji] Włochy nie interesuje”. „Mussolini określił też stosunki z Rosją jako wyraźnie złe mimo zainteresowań ekonomicznych". Natomiast Beck poinformował 9 III 1938 r. chargé d'affaires Francji w Rzymie Julesa François Blondela, że „w rozmowie, jaką miał z ministrem Ciano, ten ostatni z naciskiem stwierdził, że mimo trudności istniejących w stosunkach francusko-włoskich nie ma jego zdaniem żadnej przeszkody zasadniczej, która by stała na drodze do poprawy tych stosunków”. Poza tym ,p. Blondel został poinformowany, że więcej informacji o rozmowach rzymskich otrzyma p. amb. w Paryżu [Juliusz] Łukasiewicz dla udzielenia ich p. Delbosowi”. „Poza tym p. Minister potwierdził to, co było uprzednio komunikowane, że w rozmowach rzymskich nie było żadnych negocjacji, które by w jakikolwiek sposób sprzeciwiały się stosunkowi sojuszniczemu polsko-francuskiemu”.

Tymczasem, „zastanawiając się nad zagadnieniem czechosłowackim”, Göring w rozmowie 16 III 1938 r. z ambasadorem polskim w Niemczech Józefem Lipskim powiedział, iż „rząd Rzeszy oczekuje od rządu czeskiego złagodzenia stosunków na odcinku mniejszościowym

\footnotetext{
${ }^{6}$ Ibidem, s. 14, 90-94.

${ }^{7}$ Ibidem, s. 120-122; M. K. Kamiński, Szkice z dziejów Polski i Czechosłowacji w latach trzydziestych XX wieku, Warszawa 2014, s. 200.
} 
oraz niepogłębiania stosunku czesko-sowieckiego”. Dodał ,jednak, że na daleką przyszłość nie sądzi, by Czechosłowacja w swoim dzisiejszym kształcie mogła istnieć”. Wypowiedź marszałka Rzeszy źle wróżyła Czechosłowacji na przyszłość, i to niekoniecznie odległą. Nad Polską wisiało natomiast nie tylko niebezpieczeństwo niemieckie, ale również sowieckie. 26 III 1938 r. doszło do spotkania polskiego wiceministra Szembeka z brytyjskim ambasadorem Williamem Howardem Kennardem. Ambasador zauważył, że jednej rzeczy nie rozumie: „,naszej, tzn. polskiej”, polityki w stosunku do Czechosłowacji. „Jego zdaniem jest rzeczą jasną, że Niemcy dążą do zajęcia Czechosłowacji i pójścia dalej na Ukrainę”. „Stamtąd mogą wszak czerpać wszelkie surowce, tam też znajdą zbyt na wszelkie swoje towary" — wskazywał Kennard. „Niemcy chcą poprzez Czechosłowację rozwinąć swą ekspansję na południe i w rezultacie Polskę w ten sposób okrążą” — ostrzegał brytyjski dyplomata. „Ambasador stawia też sobie często pytanie, dlaczego uważamy [Polacy] Rosję za tak wielkie niebezpieczeństwo". Przyznaje, że ,jest ona niebezpieczna z punktu widzenia przenikania z niej wpływów komunistycznych, wykluczone jest natomiast — zdaniem Brytyjczyka — by Rosja nosiła się z zamiarami jakiejkolwiek agresji wojskowej”. Widać było, że dyplomata brytyjski ma niewielkie pojęcie o istocie państwa bolszewickiego, którego agresywny i morderczy charakter nie ulegał żadnej wątpliwości ${ }^{8}$.

W połowie kwietnia 1938 r. nastąpiła zmiana na stanowisku francuskiego premiera. Nowym rządem francuskim miał kierować Édouard Daladier. Ministrem spraw zagranicznych pozostawał nadal Bonnet. Zdaniem polskiego ambasadora w Paryżu Juliusza Łukasiewicza ,atmosfera pierwszych rozmów z nowym rządem francuskim będzie miała bardzo istotne znaczenie dla dalszego ułożenia się naszych stosunków z Francją. Z tego względu proszę pana Ministra [Becka] o rozważenie, czy nie byłoby pożądanym nie stosować w sprawie Czechosłowacji naszej dotychczasowej taktyki stosunkowo lakonicznej i formalnego odrzucenia sugestii czy żądań francuskich, ale spowodować szerszą dyskusję, która pozwoliłaby nam w sposób bardziej wyczerpujący przytoczyć nasze argumenty". Łukasiewicz wyjaśniał: „Chodzi mi o zagadnienie natury ściśle taktycznej i rozwiązanie go w ten sposób, aby strona francuska odniosła wrażenie zupełnej jasności naszego stanowiska i nie mogłaby nas posądzać o jakieś tajne porozumienie $z$ Berlinem, do czego jest niewątpliwie skłonna". „Takie postawienie sprawy dałoby nam również punkty wyjścia do ewentualnych rozmów w sprawie stosunku do polityki rumuńskiej oraz do współpracy francusko-sowieckiej w odniesieniu do zagadnień środkowo-europejskich i bałtyckich”. „Obawiam się — kontynuował Łukasiewicz, że zbyt formalne i lakoniczne ustosunkowanie się do ewentualnych żądań czy sugestii francuskich w sprawie Czechosłowacji może zaostrzyć i pobudzić niesłuszną podejrzliwość w stosunku do nas i utrudnić rozmowy w sprawach innych"9.

Beck był jednak innego zdania niż Łukasiewicz. W instrukcji z 22 IV 1938 r. informował: „Po rozważeniu sprawy nie sądzę, ażeby jakiekolwiek głębsze rozmowy z rządem francuskim na temat spraw środkowej Europy mogły dać rozsądny rezultat: Primo, nie wierzę, aby aktualny rząd zdobył się na decyzję rewizji swojej polityki, a co zatem idzie, pogłębianie dyskusji zaostrzyłoby tylko różnicę zdań. Secundo, nie jestem przekonany, ażeby rząd obecny miał cechy trwałości, bo nie wydaje mi się prawdopodobne, aby ci sami ludzie potrafili złamać organiczne wady ustroju, w którym się wychowali i porobili kariery”. „W tych warunkach — zwracał się Beck do Łukasiewicza - proszę w sprawie środkowej Europy — nadal zachować daleko idącą rezerwę". Tymczasem trwająca w dniach 27-29 IV 1938 r. konferencja londyńska przedstawicieli Francji i Wielkiej Brytanii „doprowadziła do

${ }_{9}^{8}$ PDD, 1938, s. 123-125, 138, 139, 165.

9 Ibidem, s. 219, 220. 
daleko idącego sprecyzowania i zacieśnienia sojuszu wojskowego francusko-angielskiego". Sprawy środkowoeuropejskie, a przede wszystkim kwestia Czechosłowacji, stanowiły jeden z głównych tematów rozmów londyńskich. Bonnet poinformował Łukasiewicza, że ,zarówno ministrowie angielscy, jak i francuscy są niemile zdziwieni stanowiskiem rządu polskiego, nacechowanym tak daleko posuniętą rezerwą i obojętnością, które znalazło wyraz w niedawnych rozmowach z ambasadorami francuskim i angielskim w Warszawie”. „Są oni bowiem zdania, że ekspansja Niemiec w Środkowej Europie zagrażałaby bezpośrednio bezpieczeństwu Polski i jako taka nie może być Rządowi Polskiemu obojętną" — thumaczył francuski minister polskiemu ambasadorowi. Dalej Bonnet wyjaśniał, że „projektując démarche rządu angielskiego w Berlinie oba rządy, francuski i angielski, pragnęłyby mieć zapewnioną pomoc rządu polskiego w podejmowanej próbie pokojowego załatwienia spraw grożących konfliktem pomiędzy Niemcami a Czechosłowacją. Pragnęłyby one, aby rząd polski użył swych wpływów w tym kierunku, a w każdym razie zajął takie stanowisko, aby Niemcy nie mogły mieć w trakcie negocjacyj wrażenia, iż mogą oprzeć się na Polsce"10.

Francuski minister Bonnet, pragnąc pozyskać sobie stronę polską, podczas rozmowy z Łukasiewiczem 30 IV 1938 r. ,,podkreślał parokrotnie, że Francja pozostanie zawsze wierną sojuszowi z Polską, która jest jej znacznie bliższa od Czechosłowacji”. Polscy politycy pozostawali jednak czujni, nie dając się zwieść pozorom. Obawiali się ,„prób narzucenia Polsce odpowiedzialności za losy Czechosłowacji” i zachowywali ostrożność. „Ponieważ Minister Bonnet zbyt już wiele mówił o tym, co jest naszym [polskim] interesem - wyjaśniał Łukasiewicz — uznałem za stosowne, zastrzegając osobisty charakter mych uwag, odpowiedzieć mu, co następuje:

1. Nasza sytuacja formalna wobec Czechosłowacji jest znana, łączy nas tylko pakt Ligi Narodów, w dziedzinie wzajemnych stosunków Czechosłowacja robiła od 20 lat wszystko, aby je zatruć.

2. Celem polityki polskiej jest $\mathrm{w}$ równym stopniu utrzymanie i utrwalenie pokoju, jak polityki francuskiej i angielskiej.

3. Należy raczej pozostawić każdemu państwu sądzenie o tym, co jest jego interesem, i z tym się liczyć.

4. Mówiąc o interesach Polski, rządy mocarstw zachodnich zapominają często, że mamy dwóch sąsiadów, którzy mogą być jednakowo niebezpieczni.

5. Nie należy się dziwić, jeśli niejednokrotnie konstatujemy między nami różnice zdań, co do niektórych spraw, w których każde z naszych państw jest inaczej zainteresowane”.

Łukasiewicz bardzo trafnie ujmował istotę rzeczy. Minister spraw zagranicznych Francji ewidentnie wtrącał się do spraw wewnętrznych państwa polskiego. Nie do niego bowiem należało rozstrzyganie, co leży w interesie Polski, a co nie ${ }^{11}$.

Podczas wspomnianych angielsko-francuskich rozmów w Londynie ,uzgodniona została interwencja francusko-angielska w Pradze celem skłonienia rządu czeskiego do ustępstw”. Ustalono również ,interwencję angielską w Berlinie mającą na celu zwrócenie uwagi rządu niemieckiego na powagę sytuacji i zaznaczenie, że rozwój wypadków na tym odcinku nie może pozostać obojętnym rządowi Wielkiej Brytanii”. Zdaniem Bonneta „,rząd angielski w obecnej sytuacji nie może rozszerzyć swych zobowiązań wobec Francji na Czechosłowację”. Ambasador polski w Wielkiej Brytanii Edward Raczyński „wyniósł wrażenie, że mimo prób mediacji Londynu, Anglicy zdecydowani są nie dać się wciągnąć w konflikt w Europie Środkowej i pragną uchronić przed tym Francję”. 7 V 1938 r. miała

${ }^{10}$ Ibidem, s. 219, 220, 227, 232, 233, 235, 245-247.
${ }^{11}$ Ibidem, s. 234, 235, 246, 248. 
miejsce démarche posłów angielskiego i francuskiego. Poseł francuski de Lacroix ograniczył się do krótkiej démarche ustnej wskazującej na doniosłość chwili i konieczność poniesienia przez Czechosłowację ofiar na rzecz europejskiego pokoju. Czechosłowacka prasa otrzymała instrukcje niebagatelizowania interwencji przedstawicieli Francji i Anglii i przygotowania opinii publicznej na konieczność jak najdalej idących ustępstw w dziedzinie problemu mniejszościowego. Na pytanie polskiego posła w Pradze Kazimierza Papée o postulat autonomii terytorialnej czechosłowacki minister spraw zagranicznych Kamil Krofta odpowiedział, że „o tym mowy być nie może”,

21 V 1938 r. zostały w Czechosłowacji wydane zarządzenia mobilizacyjne, obejmujące nieco więcej niż jeden rocznik wojsk technicznych i lotniczych. Wiadomości ze źródeł czeskich o koncentracji wojsk niemieckich po sprawdzeniu przez Anglików w terenie nie znajdują potwierdzenia - telegrafował poseł polski w Pradze. Poseł nie taił, że w razie wkroczenia Niemców do Czech liczyć się trzeba z „konflagracją międzynarodową”, czyli pożogą wojenną. Wiem skądinąd - pisał, że „ostatnie naprężenie angielsko-niemieckie było wynikiem ostrego wypowiedzenia się Ribbentropa podczas rozmowy z Nevilem Hendersonem, ambasadorem Wielkiej Brytanii w Berlinie”. Krofta powiedział mi - telegrafował poseł czechosłowacki w Niemczech — że ,powołanie jednego rocznika było spowodowane koncentracją sił zbrojnych niemieckich na granicach Czechosłowacji oraz rozmową Ribbentropa z Vojtěchem Mastnym [posłem czechosłowackim w Niemczech] w dniu 20 b.m., w której Ribbentrop dał do zrozumienia, że w razie rozlewu krwi w Sudetach Rzesza Niemiecka może być zmuszona ująć się za sudeckimi Niemcami. Poza tym konieczne jest podtrzymanie autorytetu władzy w krajach sudeckich”. Pierwotnie czechosłowacki sztab generalny żądał powołania pięciu roczników. Zdaniem Krofty sytuacja w kraju była opanowana, a koncentracja wojsk niemieckich, według informacji sztabu czechosłowackiego - wstrzymana. Czechosłowacja wykazała, zdaniem Krofty, ,że oparta o swoich sojuszników zdecydowana jest się bronić, a to nie chybi celu w Berlinie, a zrobiło dobre wrażenie w Londynie”. Czechosłowacki minister spraw zagranicznych uważał, że jego kraj może się bronić kilka tygodni, aż do wojny europejskiej. Jego zdaniem rozwiązanie pokojowe nie było jednak wykluczone. Natomiast w okólniku rozesłanym 23 V 1938 r. przez wiceministra spraw zagranicznych Jana Szembeka stwierdza się, że „od wczoraj konstatujemy pewne odprężenie. Przeprowadzona w Czechosłowacji mała mobilizacja dała chwilowo rządowi możliwość pewnego opanowania sytuacji”"13.

24 V 1938 r. minister Beck, ustosunkowując się do stanowiska Bonneta, wyraził nadzieję, że „niebezpieczeństwo bezpośredniej agresji niemieckiej w stosunku do Czech nie jest aktualne, dzięki czemu można sytuację rozważać bez nerwowości”. Proponowane przez Bonneta „ewentualne wystąpienie polskie w Berlinie stwarzałoby ipso facto przyjęcie przez Polskę ważności jednostronnego zobowiązania Polski, nieprzewidzianego w umowach polsko-francuskich”. Beck przyznawał, że ,,powstanie szerszego konfliktu stwarzałoby oczywiście sytuację nową, co do której Rząd Polski musi sobie rezerwować możność zbadania i decyzji”. Polski minister spraw zagranicznych zmuszony był przypomnieć, „że od początku negocjacji francusko-sowieckich Rząd Polski zastrzegł się formalnie przeciw jakiejkolwiek kolaboracji na tle tego układu, ograniczając swoje stanowisko wobec Rosji do paktu o nieagresji”. „Dzisiejsze trudności Czechosłowacji wynikły w znacznym stopniu z jej polityki wewnętrznej wobec mniejszości, przy czym mniejszość polska jest przez Czechów brutalnie pokrzywdzona" — oceniał Beck sytuację Polaków mieszkających w państwie czechosłowackim. „Poza tym zmuszony jestem ostrzec — kontynuował — że

${ }^{12}$ Ibidem, s. 242, 246, 258, 261.

${ }^{13}$ Ibidem, s. 270, 273-276. 
koncesja Pragi na rzecz jakiejkolwiek mniejszości z pominięciem Polaków wywołałaby bezzwłocznie napięcie między naszymi państwami. [...] W obecnym stanie traktowania mniejszości polskiej polska opinia publiczna nie zaaprobowałaby żadnej głębszej akcji na korzyść Czechosłowacji — dodawał polski minister spraw zagranicznych. „Potwierdzając podobnie jak 7 III 1936 r. naszą gotowość wypełnienia zobowiązań sojuszniczych w ramach istniejących umów oraz gotowość przyjaznej dyskusji na temat wszelkich nowych zjawisk, opartej na wzajemnym zrozumieniu interesów Francji i Polski, zmuszony byłem poczynić powyższe zastrzeżenia" $"$.

26 V 1938 r. ambasador Łukasiewicz zakomunikował Bonnetowi treść polskiego stanowiska. Francuski minister spraw zagranicznych przyjął spokojnie polską enuncjację, „dążąc w dyskusji do wykazania, że moglibyśmy [strona polska] przyłączyć się do akcji angielsko-francuskiej bez zaciągania nowych zobowiązań”. Bonnet prosił, aby Beck „,rozważył możliwość démarche w Berlinie nie tak wyraźnej jak angielska". Zaniepokoił się ustępem dotyczącym sprawy mniejszości polskiej w Czechosłowacji, uważając że ,nasze [polskie] stanowisko może skomplikować dodatkowo już bardzo trudną sytuację i że właściwie do tego dążymy [my, Polacy]”. Francuski minister mówił „obszerniej o Rosji Sowieckiej, powtarzając stale i kategorycznie, że uważa nas [Polskę] za pierwszego i najważniejszego sojusznika, że pragnąłby dojścia do znacznego zacieśnienia stosunków i współpracy i że od tego uzależnia stosunki z ZSRR, do których, w razie pogłębienia współpracy z nami, nie przywiązywałby istotnej wagi”. W końcu rozmowy Bonnet ,wyraził chęć zachowania kontaktu i obszernej wymiany zdań na tematy dotyczące współpracy z nami [stroną polską]"15.

2 VI 1938 r. ambasador polski w Londynie Edward Raczyński otrzymał instrukcję telefoniczną z centrali, z której wynikało, że strona polska uzyskała „oświadczenie od posła czechosłowackiego w Warszawie [Juraja Slávika], co do tego, że polska mniejszość będzie traktowana na równi z innymi, nie mamy jednak zbytniego zaufania do oświadczeń rządu czeskiego”. „Co do sytuacji ogólnej, to uważamy, że [...] gdyby rząd czeski zamierzał nadal stosować taktykę obietnic i zwlekania - to doprowadzi do konfliktu". Poniewczasie strona polska dowiadywała się, że ,według naszych wiadomości, żadnych koncentracji wojsk niemieckich na granicy czeskiej nie było”, natomiast „zarządzenia mobilizacyjne wydała tylko Czechosłowacja". Brytyjski minister spraw zagranicznych Edvard Halifax usłyszał od Edwarda Raczyńskiego, że głównym postulatem polskim jest „niedopuszczenie do żadnej dyskryminacji w odniesieniu do mniejszości polskiej w Czechosłowacji w porównaniu z mniejszością niemiecką". Przypomniał on Raczyńskiemu, że poseł czechosłowacki w Warszawie dał stronie polskiej zapewnienie, że interesy ludności polskiej zostaną zabezpieczone. Raczyński odpowiedział, że tak było w istocie, ale że „pomimo tego, nie będąc pewnym, jak będzie wyglądać w praktyce spełnienie danych obietnic, Rząd Polski uważa za potrzebne określenie $\mathrm{z}$ góry stanowiska, które byłby zmuszony zająć, gdyby się spotkał z zawodem”. Ambasador przypomniał, że „mamy realne powody niezadowolenia z sąsiada”. Lord Halifax zapewnił w sposób uroczysty, że „rząd angielski, interweniując w Pradze, a równolegle rozmawiając także z Berlinem, czyni to bezinteresownie w trosce o pokój i [...] w szczególności w Pradze wywiera silny nacisk dla spowodowania jak najdalej idącej ustępliwości ze strony rządu czeskiego”. Raczyński oświadczył Halifaxowi, że „stanowisko Polski nie może pokrywać się w danej sprawie ze stanowiskiem rządu angielskiego. Polska opinia publiczna nie zrozumiałaby bowiem w chwili obecnej radykalnej zmiany sceptycz-

14 Ibidem, s. $278,279$.
${ }^{15}$ Ibidem, s. $287,288$. 
nego i negatywnego stanowiska wobec Czechosłowacji, które jest wynikiem ponawianych przykrych doświadczeń"16.

9 VI 1938 r. poseł czechosłowacki w Warszawie potwierdził Beckowi „kategorycznie zamiar swego rządu traktowania sprawy mniejszości polskiej na równych prawach z jakąkolwiek inną mniejszością w Czechosłowacji”. Czechosłowacki dyplomata potwierdził więc klauzulę najwyższego uprzywilejowania dla strony polskiej. Beck wydał też polecenie wyrażenia zdziwienia wobec czynników francuskich z powodu potraktowania przez nie sprawy mniejszości polskiej jako kwestii drugoplanowej. Nakazał również zaniechanie angażowania się w zasadnicze rozmowy ze stroną francuską, gdyż ,sytuacja nadal nie jest dojrzała do zasadniczego wyrównania polityki polskiej i francuskiej na Wschodzie Europy, zwłaszcza wobec naiwnego traktowania tych problemów przez Bonneta, wobec tego nie warto inicjować rozmów”. „Gdyby Pan Ambasador [Łukasiewicz] odczuwał zbytni nacisk z francuskiej strony w kierunku szerszych rozmów politycznych, proszę — depeszował Beck — w razie potrzeby wyjechać na krótki urlop". Tymczasem w siedzibie francuskiego Ministerstwa Spraw Zagranicznych „osłabły podejrzenia, co do możliwości (ewentualnie uprzednio skoncertowanego z Niemcami) wystąpienia Polski w sprawie czeskiej wyraźnie przeciwko Francji”. Ustaliła się — donosił Łukasiewicz — opinia, ,że nasza dotychczasowa polityka w sprawie czeskiej wypływa z ostrożności i jest skutkiem istotnie skomplikowanego naszego położenia, a nie z góry powziętych decyzji sprzecznych z interesami Francji. Jednym słowem wierzą tu, że niezależnie od rozgrywki taktycznej w razie wojny z Niemcami Polska może stanąć po stronie Francji" ${ }^{\prime 17}$.

11 VI 1938 r. w trakcie spotkania Łukasiewicza z Bonnetem polski ambasador przypomniał, że „,w jednej z rozmów z ambasadorem francuskim w Warszawie Léonem Noëlem Beck oświadczył, że Rząd Polski nie przewiduje w żadnym wypadku agresji polskiej w stosunku do Czechosłowacji, a Noël zapytał, czy mógłby uzyskać tego rodzaju formalne zobowiązanie z naszej strony”. Strona polska nie widziała jednak potrzeby zaciągania dodatkowych zobowiązań, Bonnet natomiast sprawił, że ,rząd francuski przyjął z wdzięcznością do wiadomości oświadczenie Pana Ministra [Becka] zawarte w punkcie 6 deklaracji złożonej przeze mnie [Łukasiewicza] w dniu 26 maja i uważałby za wskazane i pożądane przystąpić do dalszych szerszych rozmów celem rozwinięcia i utrwalenia współpracy sojuszniczej”. Polski minister ,,potwierdzając posobnie jak 7 III 1936 r. naszą gotowość wypełnienia zobowiązań sojuszniczych w ramach istniejących umów oraz gotowość przyjaznej dyskusji opartej na wzajemnym zrozumieniu interesów Francji i Polski”, demonstrował dobrą wolę wobec francuskiego alianta ${ }^{18}$.

Nacisk Paryża przejawił się też w formie powoływania się na opinię francuskiego szefa sztabu gen. Maurice'a Gamelina, który w liście z 27 IX 1938 r. przypomniał marszałkowi Edwardowi Rydzowi-Śmigłemu, że ,,minęły dwa lata od czasu, kiedy dał mi Pan swoje słowo honoru żołnierza, że Polska nigdy nie znajdzie się we wrogim w stosunku do Francji obozie i dodał Pan: Jeśli chodzi o nasze przystąpienie do wojny z Niemcami przeciw Czechosłowacji, to nie może być o tym mowy [...] W Paryżu w dzień Pana wyjazdu powiedział mi Pan, że w żadnym wypadku nie wyobraża Pan sobie Polski atakującej Czechosłowację”. Wydaje się, że nie było konieczne przypominanie władzom polskim słów Rydza-Śmigłego, gdyż rząd w Warszawie poważnie traktował swoje przyrzeczenie. 15 VI 1938 r. Bonnet spotkał się z Łukasiewiczem, któremu odczytał ustępy z raportu gen. Gamelina z rozmów z marszał-

\footnotetext{
${ }^{16}$ Ibidem, s. 316-319.

${ }^{17}$ Ibidem, s. 322, 323, 326.

${ }^{18}$ Ibidem, s. 328-330.
} 
kiem Rydzem-Śmigłym. „Największy nacisk położył na zdanie następujące wypowiedziane rzekomo przez Marszałka Śmigłego-Rydza do generała Gamelina: W żadnym wypadku nie zaatakuję Czechosłowacji, daję Panu na to żołnierskie słowo honoru”. Bonnet zaznaczył, iż poleci ambasadorowi Noëlowi przedstawić Panu Ministrowi [Beckowi] ważniejsze punkty raportu gen. Gamelina. Łukasiewicz natomiast wyraził opinię, że „sprawa Czechosłowacji w jej dzisiejszym stadium byłaby w naszych stosunkach z rządem francuskim wyczerpana, gdyby Pan Minister [Beck] uznał za możliwe i wskazane oświadczyć, że nie zamierzamy atakować tego państwa i że z zastrzeżeniami co do artykułu 16 uważamy pakt Ligi Narodów za obowiązujący nas". Łukasiewicz uznał za stosowne przypomnieć Bonnetowi, że strona polska uznaje Czechosłowację za twór sztuczny. „Co do Rosji Sowieckiej zaznaczyłem — mówił Łukasiewicz — że wszelkie gwarancje od tej strony uważam za absolutnie iluzoryczne, tłumacząc to zarówno brakiem środków presji na Moskwę, jak i swoistymi celami jej polityki zagranicznej, sprzecznej z każdym dążeniem do poważnego odprężenia gdziekolwiek na świecie, a specjalnie w Europie" ${ }^{, 19}$.

Istotę stosunku dyplomacji polskiej do państwa czechosłowackiego ujął zwięźle $20 \mathrm{VI}$ 1938 r. ambasador polski we Włoszech Bolesław Wieniawa-Długoszowski. Oświadczył, że „nie chcemy szkodzić Czechom, lecz wobec ich notorycznej dla nas nieżyczliwości nie mamy ani obowiązku, ani chęci pomagać im”. W ostatnich dniach czerwca ambasador polski w Berlinie Józef Lipski odbył wyczerpującą rozmowę $\mathrm{z}$ ambasadorem francuskim w Niemczech André François Poncetem. Lipski relacjonuje: „Przypisuje on [Poncet] Polsce decydującą rolę co do możliwości utrzymania pokoju w związku z konfliktem niemieckoczeskim”. Dyplomata francuski ,uważa, że postawa nasza, niewyraźna, może powstrzymać Niemcy od zbrojnego wystąpienia wobec Czechosłowacji”. Zatem ,nie żąda już, jak to czynił Bonnet wobec Łukasiewicza, naszej démarche w Berlinie, a raczej nie wiązania się z Rzeszą w tej sprawie i zachowania sfinksowatej postawy". W Paryżu nie nastąpiła jednak zmiana podejścia francuskiego do problemu wciągnięcia Polski w system uzależnienia od Francji. 16 VII 1938 r. podczas rozmowy Becka z ambasadorem francuskim w Warszawie Noëlem ten ostatni zapytał, „,o właściwie nam [stronie polskiej] szkodzi stwierdzić na piśmie, że nie zaatakujemy Czechosłowacji. Na to Pan Minister Beck odpowiedział, że takie pytanie stawia go w pozycji gentlemana, od którego żądają, aby stwierdził na piśmie, że nie oszukuje w karty. Na pytanie Noëla, czy może to oświadczenie przesłać do Paryża, Pan Minister z naciskiem podkreślił, że żadnej deklaracji poza tym co p. Łukasiewicz powiedział w Paryżu, nie daje i że natomiast potwierdza integralnie to, co p. Łukasiewicz powiedział”. Wreszcie, „kończąc swą odpowiedź na zapytania Noëla co do powodów odmowy Polski na jego démarche, Pan Minister Beck powiedział, że nie tylko nie wiadomo, jaki użytek Czesi z tego rodzaju dokumentu mogliby zrobić, ale że nadto jest pewny, że gdyby Polska przyjęła na siebie takie zobowiązanie, wykrętna polityka czeska, do której i tak nie mamy zaufania, skorzystałaby z tego faktu, aby zdyskryminować mniejszość polską w Czechosłowacji”20.

Rok 1938 stanowił zapowiedź wydarzeń prowadzących do wybuchu drugiej wojny światowej. Z polskiego punktu widzenia istotne było to, że Polska znalazła się w obliczu wydarzeń, które przesądziły o takim, a nie innym układzie sił na arenie międzynarodowej. Główny sojusznik Polski — Francja — pragnęła za wszelką cenę wymusić od swego sprzymierzeńca zgodę na pisemne zobowiązanie, że nie zaatakuje on Czechosłowacji, gdy zagrożenie niemieckie stanie się faktem. Francuzom, a także Brytyjczykom, nie wystarczały ustne

\footnotetext{
${ }_{19}$ W. Domaniewski, Umowa w Rambouillet, „Zeszyty Historyczne”, z. 47, Paryż 1979, s. 226-228; PDD, 1938, s. 334-336.

${ }^{20}$ PDD, 1938, s. 357, 361, 376-379.
} 
polskie zapewnienia w tym względzie. Ambasador polski we Włoszech Bolesław WieniawaDługoszowski trafnie ujął istotę rzeczy: „Nie chcemy szkodzić Czechom, lecz wobec ich notorycznej dla nas nieżyczliwości nie mamy ani obowiązku, ani chęci pomagać im”. Naciski mocarstw zachodnich na Polskę trwał nieustannie do lipca 1938 r., gdy tymczasem one same nie spieszyły się z podejmowaniem zobowiązań, które chciały narzucić Warszawie. Dyplomacja francuska stosowała zatem podwójną miarę: jedną wobec siebie, a drugą wobec sprzymierzeńca. Nie wróżyło to nic dobrego dla przyszłego współdziałania Francji z Polską w wypadku wybuchu wojny światowej.

\section{Poland under the Pressure of the Western Powers (January-July 1938)}

The year 1938 was a forecast of events leading up to the outbreak of the Second World War. From the Polish point of view it was essential that Poland had found herself facing developments decisive for a certain configuration of forces on the international arena. The prime ally - France wished at all cost to force Poland to consent to a written commitment, namely, that the Polish side would not attack Czechoslovakia once the German threat became a fact. The French and the British were dissatisfied with suitable verbal assurances. Bolesław Wieniawa-Długoszowski, the Polish Ambassador in Italy, aptly expressed the very heart of the matter: "We do not wish to incur harm upon the Czechs, but in the face of their notorious ill will towards us we have neither the duty nor the willingness to help them". The pressure exerted by the Western powers, which did not hasten to assume the sort of obligations that they wished to impose upon Poland, lasted uninterruptedly until July 1938. French diplomacy applied a double standard regarding France and the Polish ally. This did not bid well for future cooperation in the case of an outbreak of a world war. 